\title{
İç Mekân Estetiğinin Satın Alma Niyeti Üzerine Etkisi ${ }^{1}$
}

\author{
Elif ŞAHIN ${ }^{2}$ ve Abdülkadir ÖZTÜRK ${ }^{3}$ \\ $\ddot{O} z$
}

Günümüzde hizmet işletmelerinde ve tüketici davranışlarında hızlı değişimler yaşanmaktadır. Bu değişim sonucunda özellikle hizmet işletmelerinin rakip firmalara karşı varlıklarını devam ettirebilmeleri müşterilere rahat ve mutlu hissedecekleri bir iç mekân tasarlamakla mümkün olabileceği düşünülmektedir. Bu çalıșmanın bașlıca amacı, iç mekân estetiği ile satın alma niyeti arasındaki ilişkinin incelenmesidir. Bu amaç doğrultusunda kapsamlı bir literatür taraması yapılmıştır. Rize ilinde faaliyet gösteren bir kafenin 390 müşterisinden elde edilen anket verileri analiz edilmiştir. Elde edilen veriler ile tanımlayıcı istatistikler, güvenirlik analizleri, açıklayıcı ve doğrulayıcı faktör analizleri yapılmıştır. İç mekân estetik unsurlarından müzik, koku ve malzemenin satın alma niyeti üzerinde etkili olduğu belirlenmiştir.

Anahtar Kelimeler: Hizmet işletmeleri, Tüketici davranışları, İç mekân tasarımı, Estetik faktörler, Satın alma niyeti

\section{The Effect of Interior Aesthetics on The Purchase Intention}

\section{Abstract}

Today, there are rapid changes in service businesses and consumer behavior. As a result of this change, it is thought that it is possible for the service enterprises to maintain their existence against the competing firms by designing an interior where customers will feel comfortable and happy. The main purpose of this study is to examine the relationship between interior aesthetics and purchase intention. For this purpose, a comprehensive literature review was conducted. The survey data obtained from 390 customers of a café operating in Rize were analyzed. Descriptive statistics, reliability analyses, difference tests, explanatory and confirmatory factor analyses were performed with the obtained data. It is determined that music, fragrance and material, which are among the aesthetic elements of the interior, have an effect on the purchase intention.

Key Words: Service businesses, Consumer behavior, Interior design, Aesthetic factors, Purchase intention

\section{Atıf İçin / Please Cite As:}

Şahin, E. ve Öztürk, A. (2022). İç mekân estetiğinin satın alma niyeti üzerine etkisi. Manas Sosyal Araștırmalar Dergisi, 11(1), 374-388.

Geliş Tarihi / Received Date: 16.02.2021

Kabul Tarihi / Accepted Date: 7.09.2021

\footnotetext{
${ }^{1}$ Bu çalışma birinci yazar tarafından Recep Tayyip Erdoğan Üniversitesi Sosyal Bilimler Enstitüsü için hazırlanmış olan "Hizmet İşletmelerinde İç Mekân Estetiğinin Satın Alma Niyeti Üzerine Etkisi: Rize İli Bir Kafe Örneği” başlıklı Yüksek Lisans tezinden üretilmiştir.

${ }^{2}$ Recep Tayyip Erdoğan Üniversitesi, Sosyal Bilimler Enstitüsü, İşletme Yüksek Lisans Mezunu, elif-58600@hotmail.com,

(iD) ORCID: 0000-0002-0093-6648

${ }^{3}$ Dr. Öğr. Üyesi - Recep Tayyip Erdoğan Üniversitesi, İktisadi ve İdari Bilimler Fakültesi, abdulkadir.ozturk@erdogan.edu.tr,

(iD) ORCID: 0000-0002-1855-8892
} 


\section{Giriş}

Modern pazarlama anlayışında hizmet işletmelerinde iç mekânın çekiciliğinin ve estetiğinin işletmelere rekabet avantajı sağladığı düşünülmektedir. Ancak hizmetlerin soyut özellikleri pazarlama çabalarını zorlaştırmaktadır. Elle tutulabilir somut bir ürünü tüketicinin isteğine göre şekillendirerek sunmak daha kolayken soyut bir ürün olan hizmeti tüketicilere sunmak daha güç olmaktadır. Hizmetlerin kendine mahsus özelliklerinin farkında olan ve müşterilerin işletmeleriyle ilgili düşüncelerini etkilemek isteyen işletme yöneticileri estetik değerden faydalanmaktadır. Estetik değeri yüksek olan mekânlarda tüketicilere verilen mesajin alg1lanması kolaylaşmaktadır (Özkan, 2007, s. 28).

Günümüz tüketicileri ihtiyaç ve isteklerinin karşılanması konusunda kendilerine farklı tecrübeler sağlayacak işletmeleri daha fazla tercih etmektedir. Hizmetlerin sunulduğu ortamda etkili bir iç mekân oluşturulması önemli bir rekabet unsuru olarak görülmektedir. Değişen tüketici profili ve artan rekabet sonucunda geleneksel pazarlama çabalarının yanında günümüzün tüketici eğilimini karşılayacak yeni pazarlama uygulamalarına ihtiyaç duyulmaktadır. Bu bağlamda modern pazarlama anlayışında yeni bir boyut olarak somutlaşan estetik pazarlama kavramı karşımıza çıkmaktadır. Pazarlamanın estetiği, toplum kültürü tarafindan şartlandırılmış estetik zevkleri, idealleri ve görüşleri göz önünde bulundurarak, tüketicilerin ihtiyaçlarını nasıl karşılayacağını anlamayı sağlamaktadır (Nozdrenko, 2018, s. 302).

Estetik pazarlama, tüketicilerin duygularını kontrol etme ve tüketiciye ulaşma hususunda en önemli unsurlardan birisidir. Kullanılan bu unsur tüketicilerde güven, canlılık, mutluluk duyguları oluşturarak satın alma isteğini teşvik etmektedir (Tosun, 2003, s. 92). Bu nedenle hedef kitlenin doğru analiz edilip, zevklerine hitap eden, ihtiyaçlarına uygun çözümler üretmek gerekmektedir (Kasap, 2014, s. 153). Doğru estetik tasarımın doğru zamanda kullanılmasıyla tüketicilerin satın alma niyetine daha başarılı bir şekilde yön verilebileceği düşünülmektedir.

İşletmelerin hedefi tüketicileri mağazaya çekerek daha fazla zaman geçirmesini sağlamak ve kâr oranını yükseltmek olduğu için işletme türü ne olursa olsun iç mekân tasarımına önem verilmesi gerektiği düşünülmektedir. Estetik pazarlamanın iç mekân tasarımındaki yaşamsal önemi, işletmelerde müşterileri çeşitli duyusal algılamalarına hitap ederek işletmenin içerisine çekme olanağı sağlanmasında yatmaktadır. Estetik açıdan iç mekân tasarımı müşteri performansında olumlu algılandığ görülmektedir (Yıldırım, Akalın ve Çağatay, 2008, s. 176). İşletmelerin büyük çoğunluğunun tüketiciyi kendisine çekmek amaciyla katlandığı iç mekân tasarım oluşturma maliyetleri bu durumun önemini göstermektedir.

Bu çalışmada hizmet işletmelerinde oluşturulan iç mekân estetik tasarımın, müşterilerin satın alma niyetleri üzerinde etkili olup olmadığını tespit etmek amaçlanmaktadır. Araştırmada kafe müşterilerinin;

- Satın alma niyeti sırasında, kafenin iç mekânını oluşturan unsurlara verdikleri önem derecesi,

- Demografik özelliklerinin, sözü edilen iç mekân estetik unsurları ve satın alma niyeti üzerindeki etkisinin belirlenmesi amaçlanmaktadır.

Araştırma amaçları ve soruları doğrultusunda öncelikle hizmet pazarlaması açısından iç mekân estetiği, iç mekân estetiğini oluşturan faktörler ve bu faktörlerin satın alma niyeti üzerine etkisiyle ilgili kavramsal çerçeve sunulmuştur. Daha sonra araştırma yöntemi açılanmış, araştırma bulgularına yer verilmiş ve son olarak da araştırma sonuçları tartışlarak önerilerde bulunulmuştur.

\section{Kavramsal Çerçeve}

\section{Hizmet Pazarlamas1}

Hizmet insanların gereksinimlerini karşılamak için, herhangi bir malla mülkiyet ilişkisi olmaksızın insanlarda doyum ve yarar oluşturan, belli bedel karşıllı̆ında satışa sunulan soyut etkinlikler olarak tanımlanmaktadır (Zengin ve Erdal, 2000, s. 47). Hizmetler soyut etkinlikleri ifade ettikleri için tüketiciler tarafindan bir tatmin ve fayda olarak algılanmaktadır. Bu anlamda yapılan tanıma göre hizmetler, insan ve makine tarafindan üretilen, tüketicilere doğrudan yarar sağlayan fiziksel olmayan ürünleri ifade etmektedir (Karahan, 2006, s. 20). Bir kuruluş veya kişi tarafından pazarlandığında tatmin ve fayda sağlayan, tümüyle gayri maddi olan ve hizmetleri satın alanların herhangi bir fiziki öğeye sahip olmadıkları faaliyet veya faydalara ise hizmet pazarlaması denilmektedir (Akdoğan, 1983, s. 125).

Hizmet sektöründe gözlemlenen gelişmeler ve hızlı büyümeler, hizmet pazarlamasına yönelik ilginin her geçen gün arttı̆̆ını göstermektedir. Geleneksek olarak mal temeline dayanarak geliştirilmiş olan 
pazarlamanın yetersiz kalması, hizmet pazarlamasının gelişmesine yol açmaktadır (Mucuk, 2014, s. 303). Bir ülke ekonomisinde, hizmet sektör oranının büyük olması o ülkenin gelişmiş olduğunu göstermektedir. Toplumların refah düzeylerinin yükselmesi ile birlikte bu sektördeki işletmelerin hizmetlere daha fazla değer verdiği söylenmektedir. Son yıllarda organizasyon alanında ve ekonomide hizmetlerin gittikçe önemi artmaktadır (Bayuk, 2006, s. 2). Başta ABD olmak üzere 1980 yıllarında çeşitli ülkelerde bankacilık, ulaşım, sigortacılık, sağlık gibi hizmet sektörü üzerindeki kayıt ve sınırlamaların kaldırılması, bu sektörde pazarlama anlayışının gelişmesini sağlamaktadır (Mucuk, 2002, s. 166). Bununla beraber mal üretimi yapan işletmeler kendilerini zorlu rekabet ortamlarında bulmaları sonucunda, yaşamlarını devam ettirmek için yeni stratejiler aramaya başlamış, buda hizmet pazarlamasıyla ilgili bilimsel çalısmalara ivme kazandırmaktadır (Yıldırım, 2014, s. 17-18).

Bir hizmetin pazarlanmasında hizmetlerin özelliği, ödeme kolaylığı, fiyatı ve düzenli servisi kadar estetik özellikleri de önemli rol oynamaktadır. Hizmet işletmelerinde estetiğin önemi; işletmelerin farklı duygusal yöntemlerle müşterileri kendine çekmesiyle ortaya çıkmaktadır. Böylelikle hizmet estetiği, müşteri tatmin ve bağlılığı yoluyla hem işletmelerin hem de müşterilerin bu durumdan yararlanmasını sağlamaktadır (Kau ve Loh, 2006, s. 101).

\section{Hizmet Pazarlaması Açısından İç Mekân Estetiği}

Estetik kavramı, iletişsimin önemli bir aşamasını oluşturmakla beraber değerleme, algılama ve bunlara verilen tepkilerle ilișkili olmaktadır. Tasarımda istenen davranışın gerçekleșmesi için verilmek istenen ilk mesajın algılanması gerekmektedir. Estetik değeri yüksek olan mekânlarda bu koşulların sağlanması kolaylaşmaktadır (Özkan, 2007, s. 28).

İşletmeler potansiyel müşteriler elde etmek ve mevcut müşterilerini korumak için farklı uygulamaları denemektedir (Bakırtaş ve Altunışık, 2009, s. 98). Her gün yüzlerce farklı reklama, markaya ve ilana denk gelen tüketicinin zihninde, firma veya marka estetik yardımıyla etkili bir algı oluşturmaktadır. Böylelikle estetik, görsel unsurlarında yardımıyla, rakipler arasından kolayca fark edilmeyi sağlamaktadır (Gemser, 2001, s. 34).

Mal veya hizmetleri rakiplerinden ayırarak müşteri memnuniyetini ve sadakatini sağlamayı amaçlayan estetik kavramı, pazarlamacılar ve araştırmacılar tarafindan pazarlamaya yaygın bir şekilde dâhil edilmektedir (Dou ve Ekiz, 2011, s. 17). Estetik her zaman kültürel üretimin merkezinde yer almaktadır. Reklam, perakendecilik ve iç mekân tasarımı gibi geniş bir alana yayılmış farklı ürün ve hizmetlerin üretiminin merkezinde estetik bulunmaktadır (Entwistle, 2000, s. 321). Estetik pazarlama terimi, birbirine benzeyen ürün ve hizmetlerin giderek arttığı bir dünyada tüketicileri estetik bakımdan tatmin etmek şartıyla, ek bir değer sağlayabileceğinin fark edildiğinde doğduğu düşünülmektedir (Kaya, 2009, s. 2-3). Mağaza estetiği, mağazanın fiziksel özelliklerinin, duyusal tecrübeleri nasıl meydana getirdiğini içermektedir. Estetik, müşterinin mağaza içerisinde neler hissettiğini belirlemekte sorumlu olmaktadır (Güler, 2001, s. 30).

Pazarlama estetiği, diğer alanlarla karşılaştırıldığında, birlikte çalışan bir organizasyon estetiğinin yapısal nitelikleri anlamına gelmektedir. Estetik müşterilerin bir organizasyonda sahip oldukları izlenim ve tepkiler için güçlü bir kaynak niteliği taşımaktadır. Dahası birçok şirketin rekabetçi pazarlardaki başarısı, sadece yüksek kaliteli mallar ya da hizmetler nedeniyle değil, aynı zamanda estetiğin de kullanılmasından kaynaklanmaktadır (Olahut ve Comıatı, 2010, s. 411). Günümüz üretim toplumunda, farklı alanlarda her gün yeni bir tasarım ve fikir ortaya çıkmaktadır. Önceleri tasarımda fonksiyonellik daha belirgin özellik iken son dönemde estetik kaygilar önem kazanmaya başlamaktadır (Karaoğlu, 2014, s. 54).

Tüketicilerin işlevsel yararın tersine hizmet deneyiminden zevk alması estetik faktörü ile bağdaştırılmaktadır. Bunun sonucu olarak hizmet işletmesi müşterileri fiziksel ortamın estetik özelliklerine karşı hassas olabilmektedir (Ryu ve Jang, 2008, s.4).Tüketicilerin farklı olarak algıladığı mağazaya ilgisi daha yüksek olmaktadır. Buda müşterinin o mekânda daha fazla zaman ve para harcamasını sağlamaktadır (Varinli ve Acar, 2011, s. 6).

\section{İç Mekân Estetiğini Belirleyen Faktörler}

İç mekân tasarımın amacı, iç mekânların psikolojik açıdan pekiştirilmesi, işlevsel açıdan gelişmesi ve estetik bakımdan zenginleşmesini sağlamaktır. İç mekân tasarımında seçilen unsurlar davranışsal, estetik ve işlevsel yol göstericilerle olmak üzere üç boyutlu modellere dönüşmektedir. Bu öğeler görsel kaliteyi belirleyerek, mekânı algılayışımızı etkilemektedir (Ching, 2011, s. 46). 
Günümüzde yeni pazarların ortaya çıkısında, ekonomik dalgalanmalarda, üretim araçlarının gelişmesinde, teknolojide ve tüketici davranışlarında hızlı değişimler yaşanmaktadır (Cordan ve Karagöz, 2013, s.2). Bu değişim sonucunda işletme sahiplerinin artan rekabete karşı ayakta kalabilmeleri ve satışlarını artırabilmeleri için tüketicilerin hoş vakit geçireceği mekânlar tasarlaması gerekmektedir (Dursun, Oskaybaş ve Gökmen, 2013, s. 235). Hizmetlerin kendine mahsus özellikleri göz önüne alındığında, tüketicilerin hizmetleri satın alırken kolay ve hızlı karar veremedikleri ortaya çıkmaktadır. Hizmetlerin emeğe dayalı olma özelliklerinden dolayı, tüketicilerin hizmetler ile ilgili karar verme zorluklarını ortadan kaldırmak için belirgin unsurların ön plana çıkarılması gerekmektedir (Karahan, 2006, s. 108).Bu bağlamda estetik faktörler, mekânın atmosferini etkilediği için önemli olmaktadır (Wakefield ve Blodgett, 1994, s. 67). Mekân içerisinde dikkat edilmesi gereken tüm bu unsurlar müşterinin satın alma niyetini olumlu etkilemektedir (Ergene, 2019, s. 352).

Yıldırım (2015) yaptığı çalışmada iç mekân estetik unsurlar kapsamında doku, renk, malzeme, koku, müzik kavramlarını incelerken, Karaoğlu (2014)iç mekân estetik etmenlerini doku, renk ve 1şıklandırma olmak üzere 3 başlık alında incelemektedir. Araştırmada Yıldıım ve Karaoğlu çalışmalarındaki estetik unsurlar bir bütün olarak ele alınacak olup renk, doku, malzeme, koku, müzik ve ş̧ılandırma olarak 6 başlık altında incelenecektir.

\section{Müzik}

Müzik, tüketicinin satın alma eğilimleri, insanların ruh hali gibi faktörlerin oluşturulmasında belirleyici nitelik taşımaktadır (Başdeğirmen ve Tunca, 2018, s. 1315). Yalch ve Spangenderg'nın (1990) yaptı̆̆1 çalışmada, tüketicilerin sevilen müzikle sunulan ürünleri daha olumlu değerlendirdikleri sonucunu elde etmişlerdir. Kara'ya göre (2011, s. 51) müzik unsuru doğrudan tüketicinin duygusunu etkilemektedir. Hizmet işletmelerinin duygusal değerlendirilmesi, arka fondaki müziğin insanları harekete geçirdiği, rahatlattığı, hüzünlendirdiği ve sevindirdiği düşünülmektedir. Müşterilerin hoşuna giden müziğin yayınlandığı mağaza ona daha fazla cazip gelebilmektedir. Bu durum tüketicinin ruh halini etkiler, müşteriyi satın almaya teşvik ederek mağaza içerisinde daha fazla zaman geçirmesini sağlamaktadır (Arslan, 2016, s. 141).

\section{Aydinlatma}

Aydınlatma, iç mekândaki üç boyutluluğun algılanmasını sağlayarak kullanılan tasarım donatılarının özelliklerini tüketicinin gözleri önüne seren önemli bir tasarım unsuru olarak tanımlanmaktadır. Bununla beraber aydınlatma, iç mekâna fonksiyonellik dışında estetik değer de kazandıran bir iç mekân tasarım unsurudur (Turgay ve Altuncu, 2011, s. 169). Mekânın hacmine göre aydınlatma türünde değişiklik göstermesi gerekmektedir. İç mekân aydınlatması 3'e ayrılmaktadır. Bunlar ana, yardımcı ve atmosfer olarak sıralanmaktadır (Ergene, 2019, s. 357). Aydınlatma, mağaza atmosferini doğrudan etkilemektedir. Örneğin, sarı ş̧ık ile aydınlatılan mekân sevimli, sıcak ve pahalı algılanır iken, beyaz ışıkla aydınlatılmış mekân soğuk ve sevimsiz algılanmaktadır. Işıklandırmanın nasıl olacağı yansıtılmak imaja bağlı olarak farklılık göstermektedir (Arslan, 2011, s. 81).

\section{Doku}

Doku iç mekânları donatmada ve tanımlamada kullanılan unsurların en belirgin karakteristiklerinden biri olmaktadır (Özkan, 2007, s. 81). Dokunsal faktörler, kişisel konfor ve estetik değerler nedeniyle müşterilerin değerini potansiyel olarak artırarak estetik açıdan hassas bir ortam yaratmaktadır (Kumar vd., 2010, s. 6). Çevresi kapalı ve büyük mağazaların içerisinde rahat hareket edebilmek için havalandırma gerekli olmaktadır (Özdemir, 2008, s. 85). Mağazanın sıcaklığı da satın alma sürecinde etkili olan bir dokunma unsuru olmaktadır. İnsan vücut yüzey sıcaklığı ile mekânın sıcaklığı arasındaki fark belirli bir değerin üstünde ise müşteri kendisini bu ortamda rahatsız hissetmektedir (Akaydın, 2007, s. 87).

\section{Koku}

Birçok satın alma kararının temelinde duyular yer almaktadır. Müşterileri mağazaya çekerek daha uzun süre kalmasını sağlayan da, mağaza içerisinde rahatsız ederek mekândan uzaklaşmasını sağlayan da koku faktörüdür (Akaydın, 2007, s. 84; McDonnel, 2007, s. 233). Kokulu mağazalardaki müşteriler, kokusuz mağazadakinden daha az zaman harcadıklarını düşünmektedir (Olivier ve Fletcher, 2000, s. 341). 
Yapılan araştırma sonucunda koku unsuru olumlu davranışa yol açarak müşteriyi satın almaya teşvik edeceği sonucuna ulaşmışlardır. Mağazadaki kokuların müşteriler üzerindeki etkileri aşağıda sıralanmaktadır (Morrin ve Ratneshwar, 2003, s. 23):

- Mekândaki koku mağaza atmosferiyle uyumluysa, tüketiciler mağaza içerisinde fazla zaman geçirseler bile kendilerini daha az zaman harcamış gibi algılamaktadır.

- Uyumlu bir kokunun var olduğu mekânlarda, tüketiciler satın alma kararı vererek harcamalarını artırdığı görülmektedir.

- İş performansı ve üretkenliği artırmaktadır.

- Tüketicinin içsel durumunu (örneğin ruh halini) düzeltmektedir.

\section{Malzeme}

Malzeme, iç tasarımı kuvvetlendirerek mekâna kimlik katan önemli faktörlerden biri olarak karşımıza çıkmaktadır. Birey ve mekân arasında duygusal bağın oluşturulmasında malzemenin rolü büyüktür (Ergene, 2019, s. 355). Malzeme bilgisi arttıkça, tasarım bilgileri de artmaktadır; böylelikle mekân içi atmosfer hedef kitleye hitap edebilmektedir (Aksaç, 2006, s. 128). Malzemeler mekânın nasıl göründüğüne dair de bilgi vermektedir. Bu malzemelerden bazılarına ender rastlanırken, bazılarına ise her mekânda rastlanmaktadır (Mesher, 2010, s. 96).

\section{Renk}

Renk faktörü mekânda görselliği ön plana çıkaran, estetik nitelikli bir görsel uygulama olmakla beraber insanlar üzerinde fizyolojik ve psikolojik etkiler bırakmaktadır (Aksoy ve Hidayetoğlu, 2019, s. 125). Renkler, mekânın işlevini gerçekleştirmek yoluyla mekân algılamasına katkıda bulunmaktadır. Kişilerin mekânı kullanma süreleri de göz önünde bulundurularak renk seçimi yapmak gerekmektedir (Özdemir, 2005, s. 399).

Bir mağazanın tamamında aynı renkler kullanılabileceği gibi farklı renklerde kullanılmaktadır. Ancak tek bir renk türü iç mekânda renk ahengi oluşturmak için yeterli olmayacaktır (Manav, 2015, s. 25). Pazarlama alanında yapılan araştırmalar ışı̆̆ında farklı bölümlerde farklı renklere yer verilmesinin, müşterinin mağaza içerisinde daha uzun süre kaldığını belirtmektedir (Orel, 2005, s. 1). İç mekânda renk kullanımı mekânın fiziksel yapısına göre şekillendiği gibi renklerin kullanıldığı yüzey de önem arz etmektedir (Özsavaş, 2016, s. 454).

\section{Satın Alma Niyeti}

Niyet, davranış ve tutum ilişkisinde anahtar pozisyonu görmektedir (Kozak ve Doğan, 2014, s. 65). Niyet, önceden karar verilmiş olan bir sonucun elde edilmesi iken davranış, kararlaştırılmış niyetler sonucunda ortaya çıkan tepkiler olarak ifade edilmektedir. Bu nedenle tüketicilerin tutumlan, niyetlerini saptamakta, niyetler de davranışları oluşturmaktadır (Fishbein ve Ajzen, 1975, s. 385).

Satın alınan ürün, satın alınacak miktarı ve satın alma zamanının saptanmasını da beraberinde getirerek satın alma niyetini oluşturmaktadır (Arslan, 2003, s. 99). Satın alma niyeti, tüketicinin uyaranlara karşı, tepkisini ortaya çıkaran en ciddi aşamalardan biri olmaktadır (Tek, 1999, s. 215).Satın alma niyeti, bir tüketicinin belirli bir ürün veya hizmete ihtiyacı olduğunu tespit ederek o ürün veya hizmeti satın almay1 tercih etmesi anlamına gelmektedir. Ya da tüketicinin bir mal veya hizmeti değerlendirdikten sonra tekrar satın almaya değer olduğunu anlaması olarak ifade edilmektedir (Madahi ve Sukati, 2012, s. 153). Başka bir tanımda satın alma niyeti ise, bir müşterinin belirli bir organizasyonu satın almak veya belirli bir kuruluştan herhangi bir ürünü satın almak için algıladığı inanç derecesi olarak bahsedilmektedir. Satın alma niyetinin özünde beklentiler ve olasillklar gibi kavramlar yer almaktadır (Bergeron, 2004, s. 117). Duyulara hitap eden etkiler genelde fiziksel etkiler olarak ifade edilmektedir. Örneğin, koku, 1şık, ses ve hava gibi unsurlar 5 duyu organı aracıllğı ile algılanmaktadır. Bu unsurlar tüketicilerin satın alma niyeti üzerinde pozitif ve önemli bir güce sahip olmaktadır (Karakaşoğlu ve Arslan, 2016, s. 228). Bir mağazanın estetik olarak ele alınması tüketicilerin mağaza seçiminde ve satın alma davranışı üzerinde güçlü etki oluşturmaktadır (Başdeğirmen ve Tunca, 2018, s. 1308).

\section{İç Mekân Estetiği ve Satın Alma Niyeti}

Morin vd. (2007) yaptıkları çalşsmada hizmet sektöründe faaliyet gösteren işletmelerin, arka planda çaldıkları müziklerin satın alma niyetlerini etkileyen süreçleri incelenmiştir. Araştırma sonucunda arka plan müziğinin hizmet ortamına yönelik müzik seçiminin atmosferik tutuma katk1 sağladığ1 gözlenmiştir. Caldwell ve Hibbert (1999) tarafindan bir restoranda yapılan araştırmada ise müşterilere dinletilen müzik 
ile satın alma davranışları arasındaki ilişkiyi incelemişler ve restoranda çalınan müzik temposu ile içecek ve yemek için harcanan miktar arasında ilişki olduğu sonucu ortaya koyulmuştur.

Bir mekândan beklenen psikolojik tesirin oluşmasında ve fiziksel işlevin istenilen biçimde yerine getirilmesinde aydınlık unsuru belirleyici rol oynamaktadır. Aydınlatma mekân içerisinde müşterileri tüm boyutları ile etkilemekte ve iç mekân tercihlerinde davranışları yönlendirmektedir (Özkan, 2007, s. 67). Aydınlatma ile ilgili yapılan araştırmalar mağazada kullanılan aydınlatmanın mağazanın imajını da etkilediğini göstermektedir (Areni ve Kim, 1994, s. 124).

Mağazanın sıcaklığı da satın alma sürecinde etkili olan bir dokunma unsuru olmaktadır. İnsan vücut yüzey sıcaklığı ile mekânın sıcaklığı arasındaki fark belirli bir değerin üstünde ise müşteri kendisini bu ortamda rahatsız hissetmektedir. Aynı şekilde kişinin bulunduğu ortam ile diş ortam arasındaki sıcaklık farkı da belirli bir değerin üstünde olması konforsuz olarak algılanıp rahatsızlıklara neden olabilmektedir. Havanın soğuk olduğu günlerde mağaza sıcak tutulması gerekirken, sıcak ve boğucu bir günde mağaza soğuk tutulmaktadır. Aksi durumda müşteri mağazada kalmak istemeyerek kaçmak istemesine sebep olmaktadır (Akaydın, 2007, s. 87; Can, Avcı ve Ethemoğlu, 2008, s. 147). Hussain ve Ali (2015) mağaza atmosferinin satın alma niyeti üzerine etkisini incelemiş ve sıcaklığın alışveriş yaparken tüketicilerin satın alma niyetlerini hiç etkilemediği sonucuna ulaşmıştır.

Koku ile ilgili yapılan araştırmalarda, mağaza içerisinde kullanılan güzel kokuların atmosferi iyileştirdiği, müşterilerin tekrar ziyaret etme isteğini ve satışları artırdığı belirtilmektedir (Spangenberg, Crowley ve Henderson, 1996, s. 77; Mattila ve Wirtz, 2001, s. 286). Anggie ve Haryanto (2011) Endonezya'da bulunan bir firın işletmesi tüketicileri satın almaya teşvik etmek amacıyla mağaza ortamında koku unsurunu kullanmışlardır.

Ryu ve Jang (2008) yapmış oldukları çalışmada ise, lüks restoranlardaki fiziksel yemek ortamı faktörlerinin (tesis estetiği, ambiyans, aydınlatma, servis ürünü, yerleşim düzeni ve sosyal faktör) algilanan kaliteye etkisini ölçmüştür. Yapılan araştırma sonucunda sonuçlar oldukça anlamlı çıkmıştır.

Demiray'ın (2016) yapmış olduğu çalışmada mağaza atmosferini oluşturan renk unsurunun içgüdüsel satın alma davranışları üzerine etkisi incelenmiştir. Araştırma sonucuna göre renk unsurunun tüketicilerin kalite algısı ve içgüdüsel satın alma süreçlerinde anlamlı bir ilişkisi olduğu sonucuna ulaşılmıştır. Hussain ve Ali (2015) tarafından yapılan bir çalışmada ise mağaza atmosferinin tüketici satın alma niyeti üzerindeki etkisi araştırılmışır. $\mathrm{Bu}$ araştırma sonucunda temizlik, koku, ışıklandırma ve mağaza düzeni satın alma niyetini önemli ölçüde etkilerken, renk unsuru tüketicinin satın alma niyetini az düzeyde etkilediği saptanmıştır.

\section{Araştırma Modeli ve Hipotezlerin Geliştirilmesi}

İç Mekân Estetik

Unsurları

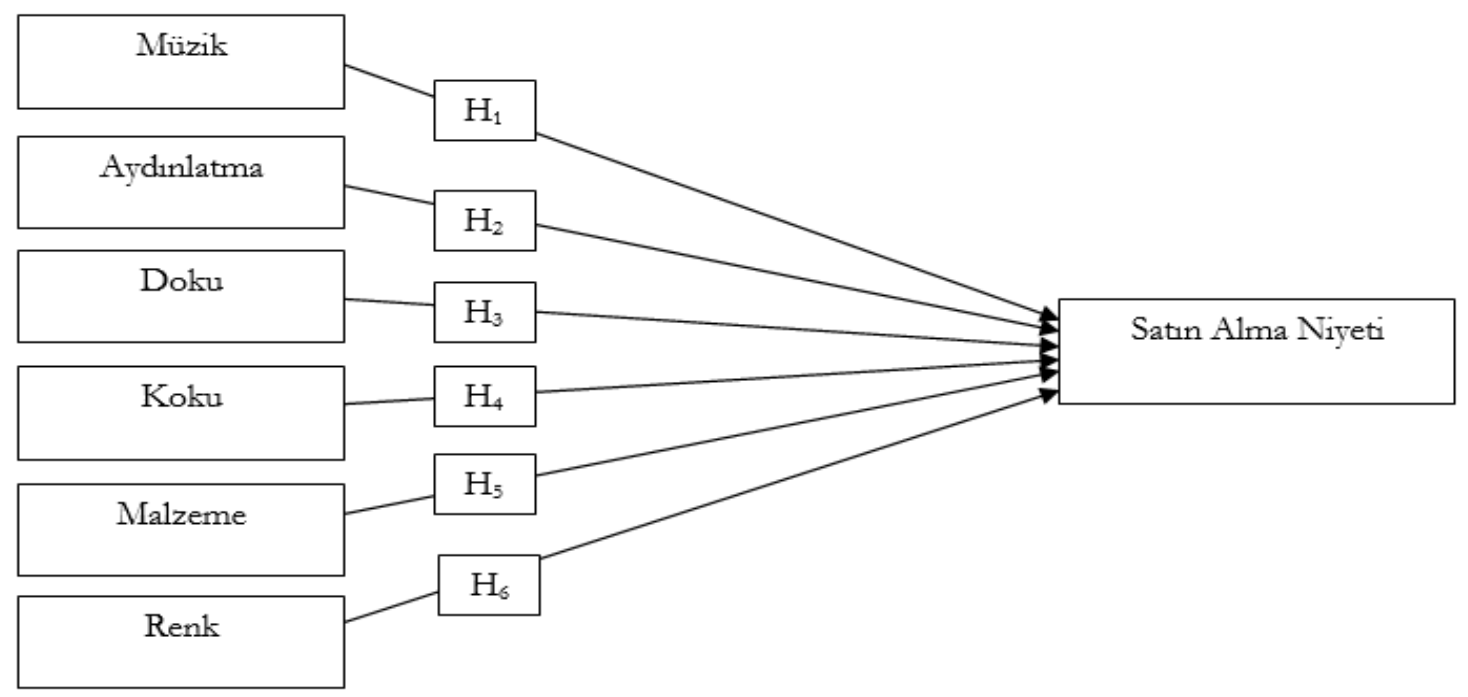

Şekil 1. Araștırma Modeli ve Hipotę̧ler 
Araştırmada kullanılan kavramsal çerçeve ile ilgili belirlenen bağımlı ve bağımsız değişkenler arasındaki ilişkileri araştırmak üzere oluşturulan hipotezler aşağıdaki gibidir; sahiptir.

$\mathrm{H}_{1}=$ İç mekân estetiğini oluşturan müzik algısı satın alma niyeti üzerinde olumlu ve anlamlı bir etkiye

$\mathrm{H}_{2}=$ İç mekân estetiğini oluşturan aydınlatma algısı satın alma niyeti üzerinde olumlu ve anlamlı bir etkiye sahiptir.

$\mathrm{H}_{3=}$ İç mekân estetiğini oluşturan doku algısı satın alma niyeti üzerinde olumlu ve anlamlı bir etkiye sahiptir. sahiptir.

$\mathrm{H}_{4=}$ İç mekân estetiğini oluşturan koku algısı satın alma niyeti üzerinde olumlu ve anlamlı bir etkiye

$\mathrm{H}_{5}=$ İç mekân estetiğini oluşturan malzeme algisı satın alma niyeti üzerinde olumlu ve anlamlı bir etkiye sahiptir.

$\mathrm{H}_{6=}$ İç mekân estetiğini oluşturan renk algısı satın alma niyeti üzerinde olumlu ve anlamlı bir etkiye sahiptir.

\section{Evren - Örneklem}

Rize il merkezinde faaliyet gösteren bir kafeden hizmet alan farklı cinsiyetten, gelir seviyesinden, meslek ve yaş grubundan tüm müşteriler bu çalışmanın evrenini oluşturmaktadır. (Etik kuralları ihlal etmemek için bu araştırmada kafe adı belirtilmemiş ve X kafe olarak tanımlanmıştır).

Ana kütlenin büyük olması nedeniyle, bahsi geçen kafeden hizmet alan müşterilerden ankete katılmaya gönüllü kolayda örneklen yöntemiyle 430 müşteri seçilmiştir. Veri toplama sürecinde anketlerin 330’u yüz yüze, 100'ü ise elektronik olarak elde edilmiştir. Toplamda 430 anket geri dönmüştür. Söz konusu anketler tutarlı bir şekilde doldurulup doldurulmama açısından incelenmiş 390 anket amaca uygun bulunarak analize dâhil edilirken 40 adet anket eksik veya hatalı doldurmadan dolayı analize dâhil edilmemiştir.

\section{Veri Toplama Araçları}

Araştırmada, veri toplama aracı olarak anket seçilmiştir. Anketler sosyal medya ve kısa mesaj ile daha önce bu kafeyi ziyaret etmiş olan müşterilere yollanıp, internet üzerinden müşterilere ulaştırılması ve ulaştırllan müşterilerden verilerin toplanmasıyla ve kafe içerisinde müşteriler ile yüz yüze görüşme yoluyla elde edilmiştir. Araştırmanın uygulama süreci 2019 yılının Nisan-Mayıs döneminde bir aylık bir süreyi kapsamaktadır. Kolayda örneklem yönteminin kullanıldığı bu araştırmada, 37 adet ifade 5 noktalı likert ölçeği ile ölçülmüsşür.

Verilerin toplanması için oluşturulan anket formu üç bölümden ve 43 sorudan oluşmaktadır. İlk bölümde müşterilerin iç mekân estetik unsur algıları ile ilgili sorular yer almaktadır. İkinci bölümde ve satın alma niyeti ile ilgili sorulara yer verilmektedir. Bu bölümlerde yer alan sorular 5’li Likert Ölçeği (1Kesinlikle Katılmıorum'dan 5-Kesinlikle Katılıyorum'a) ölçülmüştür. Üçüncü ve son bölümde ise katılımciların demografik özelliklerine ait sorular bulunmaktadır.

Araştırmada müzik faktörünün satın alma niyetini ölçmek için 9 maddeden oluşan Herrington ve Capella (1996) tarafindan geliştirilen müzik ölçeği kullanılmıştır. Araştırmada estetik faktörü oluşturan doku ölçeği 3 madde ve aydınlatma ölçeği 6 madde ile ölçülmüştür. Ölçekler Hussain ve Ali (2015) tarafindan geliştirilmiştir. Ölçek ilk olarak Türkçeleştirilmiş ve çalışmaya uygun hale getirilerek oluşturulmuştur. Koku ölçeği iki farklı çalışma birleştirilerek elde edilmiştir. Anggie ve Haryanto (2011) yapmış olduğu çalışmadan 4 soru, Hussain ve Ali'nin (2015) yapmış olduğu çalışmadan 3 soru alınarak toplamda 7 soru ile tüketicinin iç mekândaki koku algiları ölçülmüştür. Ryu ve Jang (2008) tarafindan geliştirilen ölçeğe göre "Tablo ayarları" faktörü her müşteriye hizmet vermek için kullanılan ürünleri ve malzemeleri temsil ettiği görülmektedir. Lüks restoranların fiziksel ortamları algılanan kaliteye etkisini ölçmede kullanılan 3 soruluk malzeme ölçeği Türkçeleştirerek ve uygun hale getirilerek çalışmada kullanılmıştır. Hussain ve Ali (2015) tarafından mağaza atmosferinin tüketici satın alma niyeti üzerindeki etkisini ölçmek amacıyla geliştirilen 3 maddeden oluşturulan renk ölçeği kullanılmıştır.

Araştırmada satın alma niyeti ölçeği olarak Uysal'ın (2018) kullandığ1 satın alma niyeti ölçeği kullanılmıştır. Satın alma niyetini ölçmek için 3 soru çalıssmaya göre derlenerek kullanılmıstır. 


\section{Verilerin Analizi}

Anketlerden 390 adedi numaralandırılarak değerlendirilmeye alınmıştır. Elde edilen veriler SPSS Windows 22.0 paket programına girilmiştir. Tanımlayıcı istatistiksel analizlerden sonra güvenilirlik testleri ve faktör analizi yapılmıştır. Araştırma modelinde yer alan değişkenler arasında ilişkileri analiz edebilmek için yapısal eşitlik modellemesinden (YEM)yararlanılmıştır. Değişkenler arasında nedenselliklerin test edilmesi için AMOS 21 paket programı kullanılmıştır.

\section{Bulgular}

Katılımcıların demografik özellikleri ile ilgili tanımlayıcı istatistikleri elde etmek üzere frekans analizi yapılmıştır. Bulgular tablo 1'de yer almaktadır.

Tablo 1. Araștırmaya Katılan Müsterilerin Demografik Özelliklerine Ait Veriler

\begin{tabular}{|c|c|c|c|}
\hline & & $f$ & $\%$ \\
\hline \multirow{2}{*}{ Cinsiyet } & Kadın & 240 & 61,5 \\
\hline & Erkek & 150 & 38,5 \\
\hline \multirow{3}{*}{ Yaş } & $18-25$ & 301 & 77,2 \\
\hline & $26-33$ & 72 & 18,5 \\
\hline & $34+$ & 17 & 4,3 \\
\hline \multirow{2}{*}{ Medeni Durum } & Evli & 43 & 11,0 \\
\hline & Bekâr & 347 & 89,0 \\
\hline \multirow{5}{*}{ En Son Mezun Olduğu Okul } & İlköğretim & 7 & 1,8 \\
\hline & Lise ve dengi & 168 & 43,1 \\
\hline & Önlisans & 54 & 13,8 \\
\hline & Lisans & 143 & 36,7 \\
\hline & Lisansüstü & 18 & 4,6 \\
\hline \multirow{6}{*}{ Gelir } & 500 TL ve alt1 & 152 & 39,0 \\
\hline & $501-1500 \mathrm{TL}$ & 96 & 24,6 \\
\hline & $1501-2500 \mathrm{TL}$ & 38 & 9,7 \\
\hline & 2501-3500 TL & 37 & 9,5 \\
\hline & $3501-4500 \mathrm{TL}$ & 37 & 9,5 \\
\hline & 4501 TL ve üzeri & 30 & 7,7 \\
\hline \multirow{8}{*}{ Meslek } & Kamu sektörü çalışanı & 53 & 13,6 \\
\hline & Özel sektör çalışanı & 37 & 9,5 \\
\hline & Öğrenci & 258 & 66,2 \\
\hline & Serbest meslek & 6 & 1,5 \\
\hline & İşsiz & 12 & 3,1 \\
\hline & Ev hanımı & 5 & 1,3 \\
\hline & Esnaf & 5 & 1,3 \\
\hline & Diğer & 14 & 3,6 \\
\hline
\end{tabular}

Araştırmanın örneklemini oluşturan 390 katılımcıdan \%61,5’i kadınlardan müşterilerden, \%38,5'i erkek müşterilerden oluşmaktadır. Yaş dağılımına bakıldığında müşterilerin \%77,2’lik kısmının 18-25 yaş arası gençlerden oluştuğu görülmektedir. Katılımcıların medeni durumlarına bakıldığında \% $\% 9,0$ ile bekâr müşterilerin çoğunlukta olduğu gözlemlenmiştir. Müșterilerin en son mezun olduğu okula bakıldığında $\% 43,1^{\prime}$ i lise ve dengi mezunlardan oluşmaktadır. Gelir durumuna göre dağılım incelendiğinde, ilk grup olan 500 TL ve altı gelire sahip müşterilerin \%39,0 olarak görülmektedir. Katılımcıların meslek dağılımına bakıldığında en fazla \%66,2 ile öğrencilerden, \%1,3 ile esnaf ve ev hanımlarından oluşturmaktadır.

\section{Araştırmanın Yapısal Modeli}

Araştırmada kullanılan 37 likert tipi ifade güvenilirlik analizine tabi tutulmuş ve Cronbach's Alpha değeri $\alpha=0,936$ olarak hesaplanmıştır. Böylelikle araştırmada kullanılan ölçeklerin yüksek derecede güvenilir olduğu görülmektedir. Faktör analizi sonucuna ilişkin değerler aşağıdaki tablo 2'de verilmektedir. 
Tablo 2. Değģskenlere Ait Faktör Analizi Sonuclar

\begin{tabular}{|c|c|c|c|c|}
\hline Ifade & Faktör Yükü & $\begin{array}{l}\text { Ortalama } \\
\text { Katılim }\end{array}$ & $\begin{array}{c}\text { Cronbach's } \\
\text { Alpha } \\
\end{array}$ & $\begin{array}{c}\text { Açılklanan } \\
\text { Varyans }\end{array}$ \\
\hline Faktör 1: Müzik & & & ,919 & 16,786 \\
\hline X Kafe'de arka planda çalan müzikler zevkime uygundur & ,818 & 3,37 & & \\
\hline X Kafe'de çalan müzikleri severim & ,792 & 3,26 & & \\
\hline $\begin{array}{l}\text { X Kafe'de çalan arka plan müziklerini tekrar dinlemek } \\
\text { isterim }\end{array}$ & ,790 & 3,06 & & \\
\hline $\begin{array}{l}\text { Arka planda bu müzikleri dinlemek X Kafe'de geçirdiğim } \\
\text { zamanı daha eğlenceli hale getirir }\end{array}$ & ,770 & 2,96 & & \\
\hline $\begin{array}{l}\text { Her ne zaman X Kafe'ye gitsem bu müzikleri dinlemeyi } \\
\text { arzu ederim }\end{array}$ & ,769 & 3,18 & & \\
\hline $\begin{array}{l}\text { Birlikte X Kafe’ye gittiğim kişilerinde bu müziği duymaktan } \\
\text { keyif aldığını düşünüyorum }\end{array}$ & ,720 & 3,21 & & \\
\hline $\begin{array}{l}\text { X Kafe'ye bir sonraki gelişimde bu müzikleri duymak } \\
\text { isterim }\end{array}$ & ,716 & 2,49 & & \\
\hline $\begin{array}{l}\text { X Kafe'de otururken arka planda çalan müzik kafenin } \\
\text { imajına olumlu katkı sağlar }\end{array}$ & ,594 & 3,48 & & \\
\hline $\begin{array}{l}\text { X Kafede vakit geçirirken arka planda çalan müziği rahatsız } \\
\text { edici bulurum }\end{array}$ & ,530 & 3,21 & & \\
\hline Faktör 2: Koku & & & ,906 & 15,968 \\
\hline X Kafe'nin kokusu benim tekrar kafeye gelmemi sağliyor & 809 & 3,23 & & \\
\hline X Kafe'nin kokusu beni huzurlu hissettirir & 804 & 2,74 & & \\
\hline X Kafenin kokusu beni mutlu eder & ,792 & 2,98 & & \\
\hline $\begin{array}{l}\text { X Kafe'nin kokusu kafede daha fazla zaman geçirmemi } \\
\text { sağllyor }\end{array}$ & ,789 & 3,07 & & \\
\hline X Kafe'nin kokusu beni evimdeymiş gibi hissettirir & ,789 & 2,68 & & \\
\hline $\mathrm{X}$ kafenin kokusu beni daha fazla satın almaye teşvik ediyor & ,783 & 2,86 & & \\
\hline $\mathrm{X}$ Kafe'nin kokusu beni rahatlatıyor & ,704 & 2,89 & & \\
\hline Faktör 3: Malzeme & & & 904 & 12,071 \\
\hline X Kafe'de masa düzeni görsel olarak çekicidir & ,767 & 3,79 & & \\
\hline XKafe’nin iç mekân renkleri güzeldir & ,731 & 3,53 & & \\
\hline $\begin{array}{l}\text { X Kafe'de masada kullanılan aksesuar (örneğin peçete, } \\
\text { Amerikan servisi v.b) ilgi çekicidir }\end{array}$ & ,715 & 3,57 & & \\
\hline $\begin{array}{l}\text { X Kafe'de kullanilan renkler bende olumlu bir imaj } \\
\text { yaratmaktadır }\end{array}$ & ,684 & 3,81 & & \\
\hline $\begin{array}{l}\text { X Kafe'de yiyecek/içeceklerin sunulduğu servis } \\
\text { malzemeleri (örneğin cam, porselen v.b) kalitelidir }\end{array}$ & ,683 & 3,70 & & \\
\hline $\begin{array}{l}\text { X Kafe'de kullanılan renkler bende olumlu bir alg1 } \\
\text { yaratmaktadır }\end{array}$ & ,676 & 3,69 & & \\
\hline Faktör 4: Aydınlatma & & & 885 & 11,400 \\
\hline $\begin{array}{l}\text { X Kafe’nin iç mekân ışıklandırması ürünleri benim için } \\
\text { daha cazip kılar }\end{array}$ & ,777 & 3,92 & & \\
\hline X Kafe'nin iç mekân 1şıklandırması ürünleri görünür kılar & ,775 & 3.51 & & \\
\hline $\begin{array}{l}\text { X Kafe’de ürünlerin sergilendiği alanın aydınlatılması } \\
\text { ürünün kalitesini değerlendirmeme imkân tanır }\end{array}$ & ,731 & 3,50 & & \\
\hline $\begin{array}{l}\text { X Kafe'nin iç mekân ışıklandırması orada daha fazla } \\
\text { kalmamı sağlar }\end{array}$ & ,705 & 3,64 & & \\
\hline $\begin{array}{l}\text { X Kafe'de farklı yerlerde kullanılan aydınlatmaların önemli } \\
\text { olduğunu düşünüyorum }\end{array}$ & ,616 & 3,60 & & \\
\hline X Kafe'nin iç mekân ışıklandırması hoşuma gidiyor & ,483 & 3,76 & & \\
\hline Faktör 5: Doku & & & 818 & 7,480 \\
\hline $\begin{array}{l}\text { X Kafe'de klimanın çalışıyor olması ortamda rahat olmamı } \\
\text { sağlar }\end{array}$ &, 770 & 3,95 & & \\
\hline Klimalı kafe ortamları beni rahatlatıyor & ,676 & 3,93 & & \\
\hline $\begin{array}{l}\text { Havalandırma sisteminin iyi olması X Kafe'yi tercih etme } \\
\text { sebeplerimdendir }\end{array}$ & 674 & 3,65 & & \\
\hline Faktör 6: Satın Alma Niyeti & & & 890 & 6,173 \\
\hline Gelecekte de X Kafe'den hizmet satın almayı planliyorum & 818 & 3,22 & & \\
\hline Gelecekte de X Kafeden hizmet satın almaya niyetliyim & ,779 & 3,11 & & \\
\hline $\begin{array}{l}\text { X Kafe gelecekte gideceğim kafeler arasında ilk tercihim } \\
\text { olacaktır }\end{array}$ & 631 & 3,17 & & \\
\hline
\end{tabular}

KMO:, 932

Açılelanan toplam varyans: \% 69,877 
Araştırmada yer alan tüm ölçekler için AFA sonuçlarına göre açıklanan varyansları, faktör yükleri ve Cronbach's Alpha değerleri tablo şeklinde verilmiştir. Elde edilen KMO değeri 0,932‘dir. KMO değeri 0,70‘den büyük olduğu için veri setinin uygun olduğuna karar verilmiştir. Analiz yapılan her bir faktöre ait Cronbach alfa değerlerinin 0,80 üzeri çıktığından bu faktörlerin yüksek güvenilirliğe sahip olduğu kabul edilmiştir.

İç mekân estetiği değişkenlerine ait faktör analizleri sonucuna göre, iç mekân estetiğini oluşturan değişkenler, 5 faktör altında toplanmıştır. Bu 5 faktör sırası ile "Müzik", "Koku", "Malzeme", "Aydınlatma", "Doku” olarak adlandırılmıştır. Araştırmanın gerçekleştirildiği kafede renk unsurunun mekân içerisinde çok fazla yer almamasından dolayı çalışmaya katılanlar tarafından çok iyi algılanmamıştır. Bu nedenle renk unsuru malzeme unsuru ile aynı faktöre düştüğ̈ gözlemlenmiştir. "Renk" ve "Malzeme" unsuru tek faktör altında "Malzeme" olarak belirtilmiştir. Bu durumda $\mathrm{H}_{6}$ hipotezi test edilememiştir.

Araştırmanın bundan sonraki kısmında çalışmaya ait uyum iyiliği değerleri, doğrulayıcı faktör analizi ve gerektiği takdirde analizlere ait modifikasyonlara bakılmıştır. Çalışma modeline yapılan modifikasyonlar ve bunların sonucunda elde edilen uyum iyiliği değerleri aşağıdaki gibidir.

1. Model çalıştırıldığında MZK7 Standardize Regresyon Katsayı değeri 0.429 çıkmıştır. Hair vd., (2010) göre değişkenlerin standartlaştırılmıs regresyon ağırlık tahminlerinin 0,5'ten büyük olması gerektiğinden bu değişkenin çıkarılmıştır.

2. MZK7 değeri çıkarılıp model tekrardan çalıştırılmıştır. KK6' nın KK5 ve KK7 ile yüksek oradan ilişkili olduğu belirlenmiş ve KK6 sorusu araştırmadan çıkarılmıştır.

3. Model tekrardan çalıştırıldığından MZK1 ve MZK2’nin ilişkide olduğu belirtilmiş ve değerler arasina Kovaryans eklenmiştir.

4. Model çalıştırıldığında sırasıyla KK5 ile KK7 arasına ve ML5 ile ML6 arasına önerilen şekilde kovaryans eklenmiştir.

Yukarıda yapılan öneriler sonucunda elde edilen uyum iyiliği değerleri tablo 3’teki gibidir.

Tablo 3. Arasttrma Modeline Ait Uyum İyiliği Değerleri

\begin{tabular}{lcc}
\hline Ölçütler & Sonuçlar & Kabul Edilebilir Uyum \\
\hline$\chi 2 / \mathrm{df}$ & 3,245 & $2<\chi 2 / \mathrm{df} \leq 5$ \\
GFI & 0,81 &, $80 \leq \mathrm{GFI} \leq 1$ \\
RMSEA & 0,076 & $0 \leq \mathrm{RMSEA} \leq, 08$ \\
CFI & 0,89 &, $90 \leq \mathrm{CFI} \leq 1$ \\
AGFI & 0,78 &, $80<\mathrm{AGFI} \leq 1$ \\
\hline
\end{tabular}

Doll vd., 1994:456; Mishra ve Datta, 2011: 4

Ç1kan sonuçlara göre kurgulanan yapısal modelin iyi bir uyum sergilediği görülmektedir. Tablo 4'te modelin güvenilirliğini gösteren AVE (Average Variance Extracted = Çıkarılan Ortalama Varyans) ve CR (Composite Reliability = Birleşik Güvenilirlik) değerleri yer almaktadır.

Tablo 4. Yapusal Modele Ait AVE ve CR Değerleri

\begin{tabular}{lcc}
\hline Değgiskenler & $\begin{array}{c}\text { CompositeRelaibility } \\
(\boldsymbol{C R}=\text { Birleşik Güvenilitlik) }\end{array}$ & $\begin{array}{c}\text { AverageVarianceExtracted } \\
\text { (AVE = Çוkatılan Ortalama Varyans) }\end{array}$ \\
\hline Müzik & 0,929 & 0,622 \\
Koku & 0,909 & 0,629 \\
Malzeme & 0,902 & 0,608 \\
Aydınlatma & 0,887 & 0,567 \\
Doku & 0,832 & 0,626 \\
Satın Alma Niyeti & 0,891 & 0,733 \\
\hline
\end{tabular}

CR > ,70(Hair vd., 2014) ve AVE > ,50(Fornell ve Larcker, 1981)

Elde edilen sonuçlara göre her bir değişkenin AVE ve CR değerleri istenilen aralıkta yer almaktadır. $\mathrm{Bu}$ sonuçlar birlikte çalışmaya yol analizinin yapılması uygun bulunmuştur.

Araştırmada kullanılan yapısal model bir bütün olarak değerlendirilmiş ve değişkenlere uygulanan AFA ve DFA sonucunda modelde sorun yaratan ifadeler çıkarılmıştır. Bir sonraki aşamada ise ölçeklerin güvenilirlikleri test edilerek doğrulanmıştır. Daha sonra yapısal modelde yer alan değişkenler arası kurulan ilişkiler test edilmiştir. Araştırmanın hipotezlerinde yer alan: 
1. İç mekân estetiğini oluşturan müzik algis1,

2. İç mekân estetiğini oluşturan ışıklandırma algısı,

3. İç mekân estetiğini oluşturan doku algisı,

4. İç mekân estetiğini oluşturan koku algisı,

5. İç mekân estetiğini oluşturan malzeme algısı, satın alma niyeti üzerinde etkilidir, ifadelerini ölçmek için araştırma modeline doğrulayıcı faktör analizi (DFA) yapılmıştır.

Yapısal modele ait DFA uyum iyiliği değerleri Tablo 5’te gösterilmektedir.

Tablo 5. Yapısal Modele Ait Uyum İiliüi Değerleri

\begin{tabular}{lcc}
\hline \multicolumn{1}{c}{ Ölçütler } & Sonuçlar & Kabul Edilebilir Uyum \\
\hline$\chi^{2 / \mathrm{df}}$ & 2,785 & $2<\chi^{2 / \mathrm{df} \leq 5}$ \\
GFI & 0,826 &, $80 \leq \mathrm{GFI} \leq 1$ \\
RMSEA & 0,068 & $0 \leq \mathrm{RMSEA} \leq, 08$ \\
CFI & 0,916 &, $90 \leq \mathrm{CFI} \leq 1$ \\
TLI & 0,906 &, $90 \leq \mathrm{TLI} \leq 1$ \\
AGFI & 0,793 &, $80<\mathrm{AGFI} \leq 1$ \\
\hline
\end{tabular}

Yapısal modele ait uyum iyiliği değerleri incelendiğinde tüm değerlerin istenen aralıkta olduğu ve modelin iyi bir uyum sergilediği görülmektedir. Böylelikle YEM analizi yapılarak değişkenler arasında ilişskiler test edilmiştir. YEM analizleri sonuçlarına göre hipotez sonuçları tablo 6'daki gibidir.

Tablo 6. Yapısal Model Tabminler Tablosu

\begin{tabular}{lccc}
\hline \multicolumn{1}{c}{ Değişkenler Arası } & Standartlaştırılmış Etki Katsıyı ( $\beta$ ) & P & Sonuç \\
\hline H1: Niyet <--- Müzik &, 168 & $(0,005)$ & KABUL \\
H2: Niyet <---Aydınlatma &, 029 & $(0,746)$ & RED \\
H3: Niyet <--- Doku &, 035 & $(0,656)$ & RED \\
H4: Niyet <--- Koku &, 358 & $(0,001)$ & KABUL \\
H5: Niyet <--- Malzeme &, 298 & $(0,001)$ & KABUL \\
\hline
\end{tabular}

Tablo 6'da gösterildiği gibi, müzik, koku ve malzemenin satın alma niyeti üzerine $\mathrm{p}=0.05$ düzeyinde anlamlı oldukları görülmektedir. Böylelikle $\mathrm{H}_{1}, \mathrm{H}_{4}$ ve $\mathrm{H}_{5}$ hipotezleri kabul, $\mathrm{H}_{2}$ ve $\mathrm{H}_{3}$ hipotezleri ret edilmiştir.

\section{Tartışma, Sonuç ve Öneriler}

Yapılan bu araştırma, iç mekân estetiğinin satın alma niyeti üzerine etkisini araştırmak amacıyla yapılmıştır. İç mekân estetik unsurları olarak; müzik, aydınlatma, doku, koku, malzeme ve renk değişkenleri yer almıştır. Bu doğrultuda Rize ilinde faaliyet gösteren bir kafeden hizmet alan müssterilere anket yapılarak bu müşterilerin iç mekân estetik unsurlanının satın alma niyetlerine etkisi çeşitli hipotezler kurularak incelenmiş ve elde edilen sonuçlara göre bulgular değerlendirilmiştir. Araştırmanın gerçekleştirildiği kafede renk unsurunun mekân içerisinde çok fazla yer almamasından dolayı çalışmaya katılımcılar tarafindan çok iyi algilanmadığı düşünülmektedir. Faktör analizleri sonuçlarına göre, renk ile malzeme aynı boyutlar altında çıkmıştır. Böylelikle, çalışmanın geri kalan kısmında renk boyutu malzeme boyutu ile birleştirilmiş olup, malzemeye ait ifadeler daha fazla faktör yüklerine sahip olduğundan malzeme boyutu altında değerlendirilmiştir.

Araştırmada kullanılan ölçeğin güvenilirlik analizi ile Cronbach Alfa katsayısı hesaplanmış ve ölçeğin güvenilir (Cronbach Alfa .936) olduğu belirlenmiştir. Anket çalışmasına katılanların müzik, koku ve malzeme unsurlarına satın alma niyeti sürecinde önem verdikleri sonucuna ulaşılmıştır.

Satın alma niyeti ile iç mekân estetik unsurları arasında yapılan analizler sonucunda müziğin satın alma niyeti üzerine etkili olduğu sonucu elde edilmiştir. Bu sonuçlar literatürle benzerlik göstermektedir. Morrin vd. (2007) yaptıkları çalışmada; hizmet işletmelerinde arka planda çalan müziğin satın alma niyetini etkilediğinden bahsetmiştir. Aynı şekilde Caldwell ve Hibbert (1999) tarafindan yapılan çalışmada da; restoranda müşterilere dinletilen müziğin satın alma davranışları üzerinde etkili olduğu görülmüştür. Hizmet işletmelerinde iç mekânda çalınan müziğin, tüketiciler tarafından satın alma sürecinde etkili bir 
unsur olarak görülmesi, işletmeler için dikkate alınması gereken bir durum olduğu yapılan çalışmalar sonucunda gözlemlenmiştir.

Hizmet işletmelerinde iç mekânda kullanılan koku unsurunun satın alma üzerine etkili olduğundan bahsedilmektedir. Anggie ve Haryanto (2011) yapmış oldukları çalışmada mağaza içerisinde kullanılan kokunun satın alma niyeti oluşturduğunu belirtmişlerdir. İşletmeler tüketicilerin istek ve ihtiyaçlarını karşılarken onların beğendiği kokunun mekân içerisinde kullanılması gerektiği düşünülmektedir. Araştırmanın koku ile ilgili sonuçları da Anggie ve Haryanto (2011) çalşsmasıyla benzerlik göstermektedir.

Malzeme ve satın alma niyeti arasında yapilan analizler sonucunda, malzemenin satın alma niyeti üzerine etkili olduğu görülmektedir. Çıkan sonuçlar literatürle de benzerlik göstermektedir. Ryu ve Jang (2008) yaptıklanı çalışmada restorandaki fiziksel yemek ortamı faktörlerinin algılanan kaliteye etkisini ölçmüşler ve sonuçların anlamlı çıktığı görülmüştür.

Hizmet işletmelerinin tasarımında kullanılan ışıklandırma da iç mekân estetik unsur kapsamında incelenen bir diğer faktördür. Araştırmada iç mekân tasarımında kullanılan ışıklandırma unsurunun satın alma niyeti üzerine etkisinin olmadığı görülmektedir. Işıklandırma faktörünün satın alma niyeti üzerine etkisinin çıkmaması literatürdeki çalışmalarla aynı sonucu vermemektedir. Hussain ve Ali (2015) yapmış oldukları çalışmada mağaza içerisinde kullanılan ışıklandırmanın satın alımlar üzerindeki etkisinin önemli olduğunu belirtmişlerdir. Bu sonuçla birlikte, çalısmaya katılan katılımcılara göre mekân içerinde yer alan aydınlatmanın ortamda herhangi bir farklılık yaratmadığı veya bu çalışmayla kısıtlı olan kafenin aydınlatmasının bu kafeyi tercih etmelerinde etkili olmadığından bahsedilebilir.

Doku ve satın alma niyeti arasında yapılan analizler sonucunda, doku faktörünün satın alma niyeti üzerine etkili olmadığı görülmektedir. Çıkan sonuçlar literatürle benzerlik göstermektedir. Hussain ve Ali (2015) yaptıkları çalışmada sıcaklı̆̆ın alışveriş yaparken satın alma niyetini etkilemediği belirtilmiştir.

Hizmet işletmelerinde iç mekân estetiğinin satın alma niyetine etkisi üzerine yapılan bu araştırmada müzik, koku ve malzeme tüketiciler tarafindan önemli bulunmuştur. Bu nedenle hizmet işletmesi sahipleri iç mekân tasarımında müzik, malzeme ve koku unsurlarını göz önünde bulundurmaları gerektiği yapılan araştırma sonucunda görülmektedir.

$\mathrm{Bu}$ araştırma Rize'de faaliyet gösteren bir kafe üzerinde gerçekleştirilmiştir. Araştırma sonucunda katılımcıların çoğunlukla kadın, genç yaş grubu, medeni durumu bekâr, öğrenci ve düşük gelire sahip müşterilerden oluştuğu gözlemlenmiştir. Araştırmanın yapıldığı işletmenin hedef kitlesi katılımcıların demografik özellikleri ile benzer şekilde ise koku, müzik ve malzeme unsuru geliştirilerek tüketiciye sunulabilir. Özellikle genişletilmiş hizmet pazarlama karmasında yer alan fiziksel unsurlar ve süreç değişkenlerinin tüketiciler üzerinde etkileri elde edilen sonuçlarla desteklenmiştir. Kafede zaman geçirirken arka planda çalan müziğin ve ortam kokusunun süreç esnasındaki etkisi ve kullanılan malzemelerin fiziksel unsur olarak etkisi çalışmayı özgün kılmaktadır. Ancak araştırmanın gerçekleştirildiği işletmenin hedef kitlesi yüksek gelir düzeyine sahip üst düzey müşteriler ise gelecekte bununla ilgili yeni bir çalışma yapilabilir.

Böylelikle hizmet sektöründe yer alan işletmelerin mağaza iç mekân estetiği olan müzik, koku ve kullandıkları malzemelerle tüketicileri üzerinde olumlu etkiler bırakacağı düşünülmektedir. Kendilerine özgü ve hatırlatıcı mağaza kokusu ve ortam müziği oluşturmaları, yine mağazayı tanımlayan malzemelerle de hem ortamı hem de ürün hizmet sürecini tasarlamaları önerilmektedir.

Gelecekteki çalışmalarda örnekleme alınan kafe sayısı artırılarak birbirleri arasında karşılaştırmalar yapılabilir. Araştırmada iç mekân estetik unsurlarının satın alma niyeti üzerine etkisi incelenmektedir, gelecekteki çalışmalarda ise iç mekân estetik tasarımın müşteri sadakati üzerine etkisi ölçebilir. Uygulama daha spesifik bir şekilde belirli mağaza çeşitleri (zincir mağaza, süpermarket mağazaları, hipermarket mağazaları, restoranlar vb.) üzerinde gerçekleştirilebilir.

\section{Etik Beyan}

"İ̧ Mekân Estetiğinin Satın Alma Niyeti Üz̧erine Etkisi”" başlıklı çalışmanın yazım sürecinde bilimsel kurallara, etik ve alıntı kurallarına uyulmuş; toplanan veriler üzerinde herhangi bir tahrifat yapılmamış ve bu çalışma herhangi başka bir akademik yayın ortamına değerlendirme için gönderilmemiştir. Gerekli olan etik kurul izinleri Recep Tayyip Erdoğan Üniversitesi Sosyal ve Beşeri Bilimleri Etik Kurulu’nun 09.02.2021 tarih ve 2021/32 sayılı kararı ile alınmıştır. 


\section{Kaynakça}

Akaydın, H. (2007). Perakende măgaza atmosferinin müsterilerin satm alma karar üzerindeki rolü: Eskişebir ilindeki alışveriş merkezi müsterileri ile bir arastırma (Yüksek Lisans Tezi). https://tez.yok.gov.tr/UlusalTezMerkezi/ adresinden edinilmiştir.

Akdoğan, M. Ş. (1983). Pazarlama yönetim fonksiyonları açısından hizmet pazarlaması. Erciyes Üniversitesi İ.̇.B.F Dergisi, 4(1), 123-138.

Aksaç, H. (2006). Mağą̧alar; ürün-satış-mekân etkileşimi (Yüksek Lisans Tezi) https://tez.yok.gov.tr/UlusalTezMerkezi/ adresinden edinilmiştir.

Aksoy, K. ve Hidayetoğlu, M. L. (2019). İç mekânda renk algısı araştırma yöntemleri ve sonuçları üzerine bir inceleme. SETSCI Conference Proceedings,4(3), 125-136.

Anggie, C. ve Haryanto J. O. (2011). Analysis of the effect of olfactory, approach behavior and experiential marketing toward purchase intention. Gadjab Mada International Journal of Business, 13(1), 85-101.

Areni, C., S. ve Kim, David. (1994). Theinfluence of in-storelighting on consumers' examination of merchandise in a winestore. International Journal of Research in Marketing, 11(2), 117-125.

Arslan, K. (2003). Otomobil alımında tüketici davranışlarını etkileyen faktörler. İstanbul Ticaret Üniversitesi Dergisi, 1(3), 83-103.

Arslan, M. F. (2011). Mă̆azacllkta atmosfer (2. Bask1). İstanbul: Beta.

Arslan, K. (2016). Görsel mağazacilı (1. Bask1). Ankara: Detay Yayıncılık.

Bakırtaş, H. ve Altunışık, R. (2009). Mağaza içi atmosferin tüketicilerin satın alma davranışı üzerindeki etkisi: Ampirik bir çalışma. Tüketici ve Tüketim Araștırmalar Dergisi, 1(2), 95-118.

Başdeğirmen, A. ve Tunca, M. Z. (2018). Mağaza atmosferi ve müziğin tüketicilerin satın alma davranışlarına etkilerine yönelik bir literatür araştırması. Süleyman Demirel Üniversitesi İktisadi ve İdari Bilimler Fakültesi Dergisi, 23(4), 1305-1326.

Bayuk, N. (2006). Hizmet pazarlaması ve müşteri tutma. Uluslararası Hakemli Sosyal Bilimler E-Dergisi, 10, 1-12.

Bergeron, J. (2004). Antecedent sand Consequences of SalespersonListeningEffectiveness in Buyer-Seller Relationships (Doctoral dissertation). Retrievedfromhttp:// spectrum.library.concordia.ca/8117/1/NQ96966.pdf

Caldwell, C. ve Sally, A. H. (1999). Play that one again: The effect of music tempo on consumer behaviour in a restaurant. European Advances in Consumer Research, 4(1), 58-62.

Can, M., Avc1, A. ve Etemoğlu, A. B. (2008). Teknik tesisat el kitabı (1. Baskı). İstanbul: Dora Yayıncılık.

Ching, F. D. K.(2011). İ̧ mekân tasarm (Çev: B. Elçioğlu). İstanbul: Yem Yayınları.

Cordan, Ö. ve Karagöz, E. (2013). Pop up mekân tasarımı ve pazarlama ilişkisi. Karadeniz Sosyal Bilimler Dergisi, 5(9), 1-12.

Demiray, B. (2016). Măgaza deneyiminde duyusal ögeler: ses, renk ve ışı̆̆n tüketicilerin kalite algısı ve iggüdüsel satın alma davranıslar üzerindeki etkileri (Yüksek Lisans Tezi). https://tez.yok.gov.tr/UlusalTezMerkezi/ adresinden edinilmiştir.

Dou, M. ve Ekiz, E. (2011). Differentiation through Aesthetics in Supermarkets (Master's thesis). Linköpings Üniversitet. Linköpings, Sweden. (UMI No. 01039).

Dursun, T.,Oskaybaş, K. ve Gökmen, C. (2013). Mağaza atmosferinin içgüdüsel satın almaya etkisi ve hazır giyim sektöründe bir araştırma. Marmara Üniversitesi İktisadi ve İdari Birimler Fakültesi Dergisi, 35(2), 233-260.

Entwistle, J. (2002). The Aesthetic Economy. Journal of Consumer Culture, 2(3), 317-339.

Ergene, A. İ. (2019). Perakende giyim mağazacıllğında sergileme elemanları kullanımı Keşan ve Gümülcine örneği. Mimarlle ve Yaşam Dergisi, 4(2), 349-365.

Fishbein, M. ve Arjen, I. (1975). Belief, attitude, intention, and behavior: An introduction to theory and research (1 $1^{\text {th }}$ Edition). England: Addison-Wesley.

Fornell, C. ve Larcker, D. F. (1981). Evaluating structural equation models with unobservable variables and measurement error. Journal of Marketing Research, 18(1), 39-50.

Gemser, G. (2001). How integrating industrial design in the product development process impacts on company performance. Jaurnal of product development innovation management, 18(1), 28-38.

Güler, M. (2001). Mağą̧a diş ve iş dizayn, mağaza atmosferi ve bunlarn tüketici satın alma davramıslar üzerine etkileri (Yüksek Lisans Tezi). https://tez.yok.gov.tr/UlusalTezMerkezi/adresinden edinilmiştir.

Hair, J. F., Black, W. C., Babin, B. J., ve Anderson, R. E. (2010). Multivariate Data Analysis: Overview of Multivariate Methods ( $7^{\text {th }}$ Edition). Pearson Prentice Hall: Upper Saddle River, New Jersey: Pearson Education International.

Hair Jr, J. F., Hult, G. T. M., Ringle, C. ve Sarstedt, M. (2014). A primer on partial least squares structural equation modeling (PLS-SEM). Sage Publications.

Herrington, J. D. ve Capella, L. M. (1996). Effects of music in service environments: A field study. The Journal of Services Marketing, 10(2), 26-44.

Hussain, R. ve Ali, M. (2015). Effect of store atmosphere on consumer purchase intention. International Journal of Marketing Studies, 7(2), 35-43.

Karahan, K. (2000). Hizmet pazarlaması. İstanbul: Beta.

Karahan, K. (2006). Hizmet pazarlaması (2. Baskı). İstanbul: Beta.

Karakaşoğlu, M. ve Arslan, M.F. (2016). Mağaza hizmet ortamının marka imajına ve satın alma niyetine etkisi: P\&B ve H\&M örneği. Marmara Üniversitesi Öneri Dergisi, 12(46), 223-243. 
Karaoğlu, Ö. (2014). Mobil mekânlarm iç mekân organizasyonu ve örneklerle mobil ofis tasarmlarmm analizị (Yüksek Lisans Tezi). https://tez.yok.gov.tr/UlusalTezMerkezi/ adresinden edinilmiştir.

Kasap, Ö, H. (2014). Endüstri yapılarının dönüşümü sonucunda ortaya çıkan loft yapıları ve estetik. Araştırma Makalesi, 2(2), 151-164.

Kau, A. ve Loh, E. W. (2006). The effects of service recovery on consumer satisfaction: A comparison between complainants and non-complainants. Journal of Services Marketing, 20(2), 101-111.

Kaya, İ. (2009). Pazarlama bi’tanedir! (2. Baskı). İstanbul: Babıali Kültür Yayınları.

Kozak, A, M. ve Doğan, M. (2014). Dinleme davranışının müşterinin satın alma niyeti ve satın alma davranışına etkisi: seyahat acentası satış temsilcileri kapsamında bir araştırma. Eskişehir Osmangaz̨i Üniversitesi Sosyal Bilimler Dergisi, 15(2), 57-83.

Kumar, I., Garg, R. ve Rahman, Z. (2010). Influence of retail atmospherics on customer value in an emerging market condition. Great Lakesherald, 4(1), 1-13.

Madahi, A. ve Sukati, I. (2012). The effect of external factors on purchase intention amongst young generation in Malaysia. International Business Research, 5(8), 153-159.

Manav, B. (2015). Renk-anlam-mekan ilişkisi. The Turkish Online Journal of Design, 5(3), 22-27.

Mattila, A. S. ve Wirtz, J. (2001). Congruency of scent and music as a driver of in-store evaluations and behavior. Jaurnal of Retailing, 1(77), 273-289.

McDonnel, J. (2007). Music, scent and time preferences for waitinglines. International Journal of Bank Marketing, 25(4), 223-237.

Mesher, L. (2010). İc mekân tasarımında mağaza tasarmı (Çev: F. Akder). İstanbul: Literatür Yayıncılık.

Morrin, M. ve Ratneshwar, S. (2003). Does It Make Sense to Use Scents to Enhance Brand Memory? Journal of Marketing Research, 40(1), 10-25.

Morin, S.,Dube. L.,Chebat, J. C. (2007). The role of pleasant music in servicescapes: A test of the dual model of environmental perception. Journal of Retailing, 83(1), 115-130.

Mucuk, İ. (2002). Temel pazarlama bilgileri (1. Bask1). İstanbul: Türkmen Kitabevi.

Mucuk, İ. (2014). Pazarlama ilkeleri (19. Bask1). İstanbul: Türkmen Kitabevi.

Nozdrenko, E. A. (2018). The aesthetic concept of marketing as a factor for the development of modern consumer culture. Journal of Siberian Federal University, 2(11), 299-305.

Olahut, R. ve Comiati, R. (2010). The role of the aesthetics in the making of a brand. Babes-Bolyai University of ClijNapoca, 8(2), 411-416.

Olivier, I. ve Fletcher, M. (2000). Atmospherics and the establishment of long term customer relationships in a retail environment. Sajems Ns, 3(2), 334-343.

Orel, D. F. (2005). Renklerin dünyasında mağazacılık. Bižim Market Dergisi, 1-3.

Özdemir, Ş. (2008). Müsteri odaklı mağaza yönetimi (2. Bask1). Ankara: Nobel Yayın.

Özdemir, T. (2005). Tasarımda renk seçimini etkileyen kriterler. C.Ü. Sosyal Bilimler Enstitüsü Dergisi, 14(2), $391-402$.

Özkan, A. (2007). İc mekân tasarm kuram ve yöntemleri ışı̆ğnda günümüz. Türk iş mekân tasarmoılar ve tasarmm anlayışlarna bir yaklaşım (Yüksek Lisans Tezi). https:/ / tez.yok.gov.tr/UlusalTezMerkezi/ adresinden edinilmiştir.

Özsavaş, N. (2016). İç mekân tasarımında renk alg1sı. Güzel Sanatlar Fakültesi Sanat Dergisi, 9(18), 449-460.

Öztürk, S. A. (2015). Hizmet pazarlaması kuram uygulama ve örnekler (14. Baskı). Bursa: Ekin Yayınevi.

Ryu, K. ve Jang, S. (2008). DINESCAPE: A scale for customers' perception of dining environments. Journal of Food service Business Research, 11(1), 2-22.

Spangenberg, E. R., Crowley, A. E. ve Henderson, P. W. (1996). Improving the store environment: do olfactory cues affect evaluations and behaviors? Journal of Marketing, 60(2), 67-80

Tek, Ö. B. (1999). Pazarlama ilkeleri: Global yönetimsel yaklaşım Türkiye uygulamalar (8. Baskı). İstanbul: Beta.

Tosun, N. B. (2003). Satın alma noktası reklamlarının etkisi. Iletişim Araștırmalar Etkisi, 1(1), 87-106.

Turgay, O. ve Altuncu, D. (2011). İç mekânda kullanılan yapay aydınlatmanın kullanıcı açısından etkileri. Çankaya University Journal of Science and Engineering, 8(1), 167-181.

Uysal, C. M. (2018). Mağaza atmosferi, müşteri tatmini ve tekrar satın alma niyeti ilişkisi üzerine nicel bir araştırma (Yüksek Lisans Tezi).https://tez.yok.gov.tr/UlusalTezMerkezi/ adresinden edinilmiştir.

Varinli, İ. ve Acar, N. (2011). Tüketicilerin alışveriş yaptıkları mağazayı değerlendirilmelerinde etkili olan faktörler ile sadakat arasındaki ilişki: Kayseri ilinde yapılan bir araştırma. C.Ü. İktisadi ve İdari Birimler Dergisi, 12(1), 1-20.

Wakefield, K. L. ve Blodgett J. G. (1994). The importance of servicescapes in leisure service settings. Journal of Services Marketing, 8(3), 66-76.

Yalch, R. ve Spangenberg, E. (1990). Effects of store music on shopping behavior. Journal of Consumer Marketing, 7(2), $55-63$.

Yıldırım, E, A. (2014). Hižmet pazarlamasinda kalite algilamasi: Malatyapark AVM örneği (Doktora Tezi). https://tez.yok.gov.tr/UlusalTezMerkezi/ adresinden edinilmiştir.

Yıldırım, K., Akalın, A. ve Çağatay, K. (2008). Otel yatak odalarının iç mekân tasarımının kullanıcıların algıdavranışsal performansı üzerine etkisi. Politeknik Dergisi, 11(2), 175-185.

Yıldırım, N. N. (2015). Mağaz̧a iç mekânında tasarm-imaj ilişkisi (Yüksek Lisans Tezi). https://tez.yok.gov.tr/UlusalTezMerkezi/ adresinden edinilmiştir.

Zengin, E. ve Erdal, A. (2000). Hizmet sektöründe toplam kalite yönetimi. Qafqaz Universitesi Dergisi, 3(1), 43-56. 


\section{EXTENDED ABSTRACT}

It is very difficult for the services to be evaluated by consumers due to their unique features. While it is easier to present a tangible product by shaping it according to the consumer's wishes, it is more difficult to offer the service, which is an abstract product, to the consumers. Business managers who are aware of the intangible features of the services and want to increase the customer satisfaction with their businesses can influence the customers' thoughts about the service by taking advantage of physical factors. As a result of the changing consumer profile and increasing competition, there is a need for new marketing practices that will meet today's consumer trend as well as traditional marketing efforts. In this context, the concept of aesthetic marketing, which has become a new dimension in the modern marketing approach, appears. Aesthetic marketing is one of the most important factors in controlling the emotions of consumers and reaching the consumer. Factors such as music, lighting, texture, scent (olfactory), material and color, which are the aesthetic elements of the interior, provide convenience when service businesses evaluate their customers. For this reason, interior aesthetic elements are of great importance in service businesses. The aim of this study is to determine whether the interior aesthetic design created in service businesses has an effect on the purchasing intentions of the customers. The results of this research include customers who receive service from a cafe that is thought to use interior aesthetic elements more effectively than other cafes. In the research, the survey technique was chosen among the data collection methods. The surveys were sent to customers who had previously visited this cafe via social media and by text message, and were delivered to customers over the internet and collected by collecting data from customers and through face-to-face meetings with customers in the cafe. Due to time constraints, the data source was limited to 430 people who had previously purchased services from this cafe between April and May 2019 and volunteered to participate in the survey. At the end of the data collection process, 330 of the questionnaires were filled manually and 100 of them were filled online. The questionnaires in question were examined in terms of whether they filled out consistently or not, and 390 questionnaires were included in the analysis after they were found suitable for the purpose. The questionnaire form created to collect the data consists of three parts and 43 questions. The first part includes questions about customers' perceptions of interior aesthetic elements. The second part includes questions about the purchase intention. In the third and last part, there are questions about the demographic characteristics of the participants. Before the questionnaire form was put into practice, a pre-test was applied to a group of 40 people suitable for sampling in order to measure its understandability and validity. In the light of the results obtained, it was determined that the questionnaire was understandable and the questionnaire application started. The data obtained from 390 questionnaires were analyzed with SPSS Windows 22.0 package program. After descriptive statistical analysis, reliability tests and factor analysis were performed. In order to test the hypotheses developed for the research model, structural equation modeling (SEM), $t$ test and ANOVA analysis were used. According to the results of the research, the majority of the participants in the survey study consists of women with a rate of $61.5 \%$. According to the age group of the participants, $77.2 \%$ of them are customers between the ages of $18-25$. Considering their marital status, it consists of singles with a rate of $89.0 \%$. Considering the educational levels of the participants, $43.1 \%$ are high school graduates and $36.7 \%$ are graduates. According to the results of this study, it was concluded that there is a significant difference on the purchase intention of customers of different genders. When it was checked whether there was a significant difference in the marital status of the participants on the purchase intention or not, it was seen that there was a significant difference. The reason for this difference is thought to be due to the fact that single customers prefer such places more than married customers. When the level of education differs according to purchase intention, it is seen that there is no difference in education level on purchasing intention. However, it was concluded that the participants in different age groups differ in terms of purchase intention. The Cronbach's Alpha coefficient value of the scale used in the study was found to be 0.942 , and this value is reliable. According to the participants, it was concluded that music, scent (olfactory) and material elements are important in the purchase intention process. In the study, it is seen that the lighting element used in interior design has no effect on the purchase intention. As a result of the analysis between texture and purchase intention, it is seen that the texture factor does not affect the purchase intention. It was observed that the questions regarding the color element were in the same factor as the questions of the material element. Due to the lack of color element in the cafe where the research was conducted, it was not perceived very well by the consumers. "Color" and "Material" element has been evaluated under a single factor by naming it as "Material". 